\author{
BARTOSZ MITKIEWICZ \\ Uniwersytet Kardynała Stefana Wyszyńskiego \\ $w$ Warszawie
}

\title{
W KRĘGU WSPÓŁCZESNEGO ETOSU WYCHOWAWCY
}

\section{AROUND THE ETHOS A MODERN, TEACHER}

\section{Streszczenie}

Pojęcie wychowania nie jest terminem jednoznacznym. W swej strukturze zawiera proces wychowawczy, bądź rezultat tego działania. Zawsze jest jednak działaniem zawierającym się w schemacie pytań: kto?, co?, jak?, po co? w imię czego? Odnalezienie odpowiedzi na te pytanie pozwoli odnaleźć, drogę którą pomoże współczesnym pedagogom dokonać powrotu do świata fundamentalnych wartości, uzasadniających sens relacji wychowawczych oraz wyboru wizji wychowywanego człowieka.

\section{Słowa kluczowe}

Wychowawca, wartość, aksjologia, ethos wychowawczy.

\begin{abstract}
Abstrakt
Concept of upbringing isn't a straightforward. In it's structure, in contains pedagogical process or the result of an activity. However, it's always an activity which is included in questions scheme: Who? What? How? What for? In the name of what? The answer to this questions will allow to find a way, which is going to help modern educators make a return to the world of fundamental values, which justify a sense of pedagogical relationships and also make a choice of educated human being vision.
\end{abstract}




\section{Key words}

Tutor, value, axiology, pedagogical ethos.

Nauczyciel jest rodzajem formy, w której wychowanek nabiera odpowiednich ksztaltów. Nauczycielstwo nie jest zawodem, ale powołaniem polegajacym na dawaniu siebie bez żadnych ograniczeń, jest miłościq dusz ludzkich.

Jan Władysław Dawid

\section{WPROWADZENIE}

Edukacja w znacznym stopniu wyznacza życiowe losy ludzi, stanowi o szansach rozwojowych społeczeństw, oraz umożliwia przemiany cywilizacyjne. Jakość edukacji zależy od wielu czynników, a wśród nich szczególną rolę odgrywa przygotowanie nauczycieli, ich osobowość i stosowane metody pracy. Zrozumiałe jest więc odwieczne zainteresowanie sprawami zawodu nauczycielskiego. Problemy pracy tej niezwykle ważnej w życiu społecznym grupy zawodowej wydają się powszechnie znane, gdyż obowiązek szkolny sprawia, że prawie wszyscy mamy jakieś doświadczenia, obserwacje i poglądy dotyczące nauczycieli.

Pedagoga zwykło kojarzyć się z osobą o niepodważalnym autorytecie, z profesjonalistą, który posiada określoną wiedzę z dziedziny wychowania. To osoba towarzysząca, odnosząca się z troską i szacunkiem do potrzeb wychowanka. Tymczasem, słuchając, coraz to pojawiającego się medialnego szumu na temat polskiej szkoły i nauczycieli, można odnieść wrażenie, że dziś zawód ten wykonują sami nieudacznicy. Przychodzą do pracy wiecznie zdenerwowani, niezadowoleni, sfrustrowani xxi nieszczęśliwi. Przerzucają swoje życiowe problemy i zawodowe porażki na biedne, grzeczne dzieci. Nie potrafią nawiązać kontaktu i zrozumieć oczekiwań ich rodziców. Wiecznie wołają o podwyżki i z uporem wbrew prawom ekonomii bronią swoich przywilejów. Taki 
obraz edukacji jest jak najbardziej mylący. Owszem mogą zdarzyć się takie jednostki, ale z pewnością nie jest to ogólny stan polskich nauczycieli.

Obecnie, po raz kolejny w historii jesteśmy świadkami pokoleniowej wymiany kadry nauczycielskiej. Jednakże wciąż w naszej oświacie istnieje zapotrzebowanie na nauczycieli - wychowawców z powołania, kochających uczniów, prawdę i ustawicznie doskonalących swoje umiejętności. Zarówno osoby podejmujące zatrudnienie w szkole, jak i ich starsi koledzy wiedzą o tym, że jest to praca trudna, odpowiedzialna i słabo opłacana. Chcą jednak uczyć oraz wspomagać rozwój młodego człowieka.

Współczesna psychologia i pedagogika kładą duży nacisk na proces samorealizacji oznaczający, że wykonywana praca zawodowa powinna być czynnikiem umożliwiającym zadowolenie i satysfakcję. Wykonywanie zawodu nauczyciela powinno łączyć się z zamiłowaniem, pasją i powołaniem. Obok zadań dydaktycznych każdy nauczyciel pełni w szkole również rolę wychowawcy. Niestety, często owa druga rola bywa niedoceniana nawet przez samych nauczycieli. Wprawdzie w dokumentach opracowanych przez Ministerstwo Edukacji Narodowej wyznaczających kierunki reformy znajdujemy wyraźne odniesienia do tej kwestii, to jednak w świetle oglądu ogółu materiałów traktujących o reformie, wychowanie pozostaje nadal w cieniu działań łączących się z określeniem filozofii nauczania, założeń programowych szkół różnych stopni, podstawy programowej kształcenia, czy też ramowych planów nauczania, nie wspominając już o zarządzaniu i nadzorowaniu oraz finansowaniu oświaty. ${ }^{1}$ Przyczyn takiego stanu rzeczy jest o wiele więcej, aczkolwiek można je łatwo sprowadzić do tezy, że obecna forma pracy w szkole oraz główna troska władz, skupiają się bardziej na wynikach nauczania, niż na efektach wychowawczych. Co więcej tok studiów pedagogicznych przygotowuje nauczycieli lepiej do pracy dydaktycznej,

${ }^{1}$ Por. J. A. Malinowski, Nauczyciel jako dobry wychowawca, Wychowanie szkolne a reforma sytemu edukacji, [na:] http://www.szkolna.pl/akapit/nauczyciel.html, $\mathrm{z}$ dn. 19.10.2008. 
niż wychowawczej. ${ }^{2}$ Skoro więc szkoła ma stać się szkołą wychowującą trzeba nam na nowo spojrzeć na rolę wychowawcy.

\section{UJECIE TERMINOLOGICZNE POJECIA WYCHOWAWCA}

Wśród wszystkich pojęć pedagogicznych terminy wychowanie i wychowawca, sa jednymi z najtrudniejszych do zdefiniowania. Wynika to z faktu, iż dotyczą materii, w której toczy się długotrwały spór naukowy o ogromnych konsekwencjach praktycznych. Dzisiejsi realizatorzy wychowania to, zdaniem Wojciecha Pomykały, nie tylko rodzice, wychowawcy i nauczyciele, ale wszyscy; począwszy od pracodawcy przez wszelkiego rodzaju idoli, po redaktorów pracujących w mediach, którzy, oddziaływując na drugą osobę, wpływają na kształt jej osobowości. Zadaniem owych szeroko rozumianych autorytetów, jest wpływanie na względnie trwałe zmiany zachodzace $\mathrm{w}$ rozwoju człowieka. ${ }^{3} \mathrm{~W}$ podręcznikowej syntezie na temat wychowania wyróżnia się cztery definicje tego procesu: a) prakseologiczne (uwzględniające społeczne oddziaływanie dorosłych), b) ewolucyjne (podkreślające naturalny rozwój), c) ekologiczno-sytuacyjne (obejmujące warunki i sytuacje środowiskowe) oraz d) adaptacyjne (obejmujące charakter i osobowość wychowanka). ${ }^{4}$

Pierwszym polskim słownikiem, w którym wyjaśnione zostaje hasło wychować, jest Słownik języka polskiego S. B. Lindego z roku 1860. Wychować znaczy tam tyle, co „wyżywić aż do wzrostu”, „odchować”, „wykarmić, wyżywić, dać dostateczne wyżywienie”; „wychowywać młodego człowieka, wychowanie, ćwiczenie i naukę mu dawać, kształtować go na człowieka". Odpowiednikiem znaczeniowym polskiego wychowania jest grecki termin paideia. Etymologicznie wyraz ten oznaczał początkowo uprawę roślin i hodowlę, a w znaczeniu „hodowli (ży-

\footnotetext{
2 Por. W. Prokopiuk, Orientacja aksjologiczna, [w:], (red. Z. Bartkowiak, M. Kowaluk, M. Samujło), Nauczyciel kompetentny, teraźniejszość i przyszłość, Lublin 2007.

3 Por. W. Pomykało, Wychowanie, [w:] Encyklopedia pedagogiczna, W. Pomykało (red.), Warszawa 1993, s. 919-920.

4 Por. A. Solak, Człowiek i jego wychowywanie, Zagadnienia wybrane, Tarnów 2002, s. 16.
} 
wienia) dzieci" pojawił się po raz pierwszy u Ajschylosa. Inni autorzy (Arystofanes, Tucydytes) rozumieli termin paideia jako wykształcenie praktyczne, przygotowujące młodzież do bycia dobrymi obywatelami polis. Za głównego teoretyka paideia uważa się jednak Platona, dla którego jest to proces obejmujący całe życie człowieka, polegający na formowaniu go w oparciu o idealny obraz bytu i prowadzący do oglądu prawdziwej, idealnej rzeczywistości. ${ }^{5}$

W ujęciu encyklopedycznym wychowawcę definiuje się jako osobę odpowiedzialną za koordynację i prowadzenie pracy wychowawczej w powierzonej mu klasie. Pedagoga kojarzy się zwykle z osobą o niepodważalnym autorytecie, z profesjonalistą, który posiada specjalistyczną wiedzę z danej dziedziny i co istotne używa właściwych metod pedagogicznych. Ponadto wychowawca to ktoś, kto rozumie całego człowieka, dostrzega jego wszystkie sfery. Dojrzały wychowawca potrafi także chronić wychowanka przed jego własną słabością. Wychowanie jest bowiem prowadzeniem wychowanka ku pełni człowieczeństwa, w kontekście fundamentalnych, ogólnoludzkich prawd i wartości. ${ }^{6}$

\section{WYCHOWAWCA - W POSZUKIWANIU WZORU}

Analiza dziejów wychowania oraz myśli pedagogicznej dowodza, że wyodrębnienie $\mathrm{z}$ grona nauczycieli odrębnej kategorii wychowawców, związane było z przemianami w sposobie zdobywania kwalifikacji w zawodzie nauczyciela, a także ewolucją potrzeb w zakresie opieki i wychowania. Poglądy tradycjonalistyczne, patriarchalne ujmują wychowawcę jako osobę kochająca, sprawiedliwą, czcigodną, wzywającą do posłuszeństwa i szacunku, a wszelkie emocje podporządkowane są rozumowi. Każde wychowanie zakłada zawsze jakąś filozofię człowieka, określa ona cel, do którego kierujemy i prowadzimy wychowanka.

5 Por. A. Salamucha, Definicje wychowania w literaturze pedagogicznej, [na:] http:// www.kul.lublin.pl/ $\neg$ art_3322.html., z dn.23.10.2008.

${ }^{6}$ Por. W. Okoń, Nowy Stownik Pedagogiczny, Warszawa 2004, s. 451; Cz. Banach, Nauczyciel, [w:], (red. T. Pilch), Encyklopedia Pedagogiczna XXI wieku, t. 3, Warszawa 2005 , s. 549-543. 
Jan Jakub Rousseau uważał, że najważniejszym zadaniem wychowawcy jest brak ingerencji w proces wychowania, gdyż każdy człowiek jest z natury dobrym. W ujęciu Jacquesa Maritaina natomiast owym celem, jest takie formowanie człowieka, czy też kierowanie jego rozwojem, poprzez który udoskonali się w swoim człowieczeństwie, a nie jedynie zdobędzie maksymalna wiedzę. Proces wychowania, uwzględniając zdobycze naukowe, ma jedynie dopomagać w ich rozwoju. ${ }^{7}$

Bardzo interesujący obraz wzoru wychowawcy, odnajdziemy wśród chrześcijańskich pedagogów. Dla przykładu, w salezjańskiej metodzie ks. Jana Bosko, wychowawca to głównie formator moralno-religijny, ktoś, kto jest obecny i uczestniczy w życiu wychowanka. Ks. Bosco, wybitny XIX wieczny pedagog, tworząc swój system prewencyjny, intuicyjnie i genialnie wyczuł, że należy skonstruować system wychowania integralnego, poprzez który młodzi ludzie otrzymają pomoc w rozwoju naturalnym, kulturowym i duchowym. U podstaw jego pracy i działalności wśród dzieci i młodzieży leży chrześcijańska wizja człowieczeństwa oparta na rozumie, religii i miłości wychowawczej. ${ }^{8}$ Omawiając różne koncepcje wychowawcze, warto wspomnieć o wybitnej polskiej pedagog Marii Grzegorzewskiej. Ona to, jako jedna z pierwszych, podnosiła zagadnienia deontologii nauczycielskiej twierdząc, że prowadzenie procesu dydaktyczno-wychowawczego w znaczącym stopniu zależy od postawy pedagoga, określanego przez nią jako budowniczego świata i jego przyszłości. Najpełniej i najbardziej wszechstronnie funkcję wychowawcy w dziejach polskiej pedagogiki opisał wspomniany już wcześniej Janusz Korczak. Jego nowatorska myśl dotyczyła poszukiwań nowego modelu pedagoga, który byłby opiekunem, partnerem wy-

\footnotetext{
7 Por. J. Maritain, Od filozofii czlowieka do filozofii wychowania, [w:], S. Wołoszyn (red.), Źródła do dziejów wychowania i myśli pedagogicznej, Myśl pedagogiczna w XX wieku, t. 3, Kielce 1998, s. 134-135.

8 Por. J. Wilk, W poszukiwaniu wzoru współczesnego wychowawcy, [w:] Współczesny wychowawca w stylu księdza Bosko, Materiaty z sympozjum z okazji 100-lecia pracy Salezjanów w Polsce, Katolicki Uniwersytet Lubelski 16-17.04.1998, (red. J. Wilk), Lublin 1998, s. 8. O metodzie św. ks. Jana Bosko por. szerzej w: Jestem wychowawca. Model pracy z uczniem i klasq szkolna wedtug systemu prewencyjnego Jana Bosko, (red. K. Franczak), Warszawa 2004.
} 
chowanka. To osoba towarzysząca, odnosząca się z troską i szacunkiem do dziecięcych potrzeb, a jednocześnie szanująca swoją rolę i miejsce. ${ }^{9}$

We współczesnej metodzie pracy socjalnej pedagog, wychowawca pełni role "groupworkera". Staje się organizatorem pracy zespołowo-grupowej, jest liderem rozdzielającym zadania, koordynującym i zarządzającym. W literaturze przedmiotu spotkać się można również z postulatem humanistycznego podejścia do uczniów w procesie wychowawczym. Obecnie w myśl nowej doktryny edukacyjnej, hołdującej demokracji i swobodnemu rozwojowi jednostek, odwróceniu uległa dotychczasowa hierarchia celów kształcenia i wychowania. Na pierwszym miejscu stawia się dziś kształtowanie osobowości i postaw, w dalszej kolejności rozwijanie umiejętności, a dopiero na samym końcu wyposażenie wychowanków w wiedzę. Mieczysław Łobocki uważa, że najważniejszym czynnikiem warunkującym owo podmiotowe funkcjonowanie jest uznawanie każdego z uczniów przez nauczycieli, za jednostkę w pełni autonomiczną. Autor słusznie poszerza ów dialog o empatię, czyli wczuwanie się przez wychowawców w wewnętrzny świat przeżyć i doznań wychowanków. ${ }^{10}$

Dokonując podsumowania dotychczasowych rozważań można wskazać na cztery zasadnicze funkcje wychowawców, o których wspominają wszyscy wymienieni wyżej wybitni pedagodzy. Należą do nich funkcje: dydaktyczna, wychowawcza, opiekuńcza $i$ wspierajaca. Ich podstawowym celem pedagogicznym, jest urzeczywistnienie człowieczeństwa w podopiecznych. Będzie to o tyle trudne zadanie, o ile wychowawca sam nie będzie potrafił kierować się w życiu i pracy powszechnie obowiązującymi normami i wartościami.

\section{AKSJOLOGIA W SYSTEMACH WYCHOWAWCZYCH}

Znamienną cechą współczesności jest trudność nakreślenia fundamentalnych wartości. Usiłuje się to różnie nazywać: kryzysem wartości,

9 Por. S. Wołoszyn, Janusz Korczak, Warszawa 1982, s. 119.

10 Por. M. Łobocki, $W$ trosce o wychowanie w szkole, Kraków 2007, s. 11-13, por. także: T. Lewowicki, Przemiany doktryny $i$ teleologii edukacji a funkcje szkoty, [w:] (red. T. Gospodarka, Z. Jasiński), Edukacja w procesie przemian cywilizacyjnych i kulturowych, Opole 1993, s. 11. 
opuszczonej przestrzeni. Tymczasem wychowanie od zawsze związane było ściśle z wartościami, tradycją, autorytetami. Dziś te pojęcia i obszary, pozostające ostoją stałości, stają się niewygodne. Jednakże ich brak staje się nie tylko przyczyną dylematów współczesnego wychowania, lecz również zagubieniem tożsamości wychowawcy. ${ }^{11}$

We współczesnej myśli pedagogicznej słusznie wyraża się przekonanie, że proces wychowania zależy od właściwego doboru i przekazu wartości. Wymiar aksjologiczny pomaga człowiekowi rozpoznać sens i cel życia oraz odgrywa istotną rolę w procesie rozwoju indywidualnego i społecznego rozwoju. Nie bez znaczenia zatem w tym obszarze pozostaje funkcja wychowawcy, który powinien sam odnaleźć swoje miejsce w odniesieniu do świata systemu wartości. Znajomość typologii i hierarchii wartości powinna odgrywać znaczącą rolę przy tworzeniu programów wychowawczych oraz ich realizacji. Jednakże podstawową zdolnością wychowawców jest nie tyle przekazywanie samej wiedzy o wartościach, lecz pomoc $\mathrm{w}$ ich rozumieniu, rozpoznawaniu i kierowaniu się nimi w życiu. Warto pamiętać, że - tworząc własny system wartości - wpływa on bardzo często na kształtujące się postawy wychowanków. ${ }^{12}$,Kompetencje aksjologiczne nauczyciela - jak pisze E. Kobyłecka - sq podstawa jego podmiotowości. Wiaża się bowiem z takimi wartościami, jak: odpowiedzialność, wolność, godność, podmiotowość". ${ }^{13}$

W Ustawie z dnia 7 września 1991 r. o Systemie Oświaty czytamy: „Nauczanie i wychowanie, respektujac chrześcijański system wartości, za podstawe przyjmuje uniwersalne zasady etyki. Ksztatcenie $i$ wycho-

${ }^{11}$ Por. H. Kwiatkowska, Tożsamość wychowawcy, [w:] Wychowanie Pojęcia Procesy - Konteksty, (red. H. Dudzikowa, M. Czerepaniak-Walczak), Gdańsk 2007, s. 21

12 Por. B. Wojciechowska-Charlak, Aksjologiczne kompetencje nauczyciela, [w:] Nauczyciel kompetentny, teraźniejszość i przyszłość, dz. cyt., s. 73-74; por. także: O. Speck, Trudności wychowawcze, być nauczycielem w czasie zmian społeczno-kulturowych, Gdańsk 2007, s. 102-103; W. Brezinka, Wychowanie i pedagogika, W dobie przemian kulturowych, Kraków 2005, s. 25nn.

13 Zob. E. Kobyłecka, Nauczyciel wobec współczesnych zadań edukacyjnych, Kraków 2005, s. 48. 
wanie stuży rozwijaniu u młodzieży poczucia odpowiedzialności, miłości ojczyzny oraz poszanowania dla polskiego dziedzictwa kulturowego, przy jednoczesnym otwarciu się na wartości kultur Europy i świata. Szkoła winna zapewnić każdemu uczniowi warunki niezbędne do jego rozwoju, przygotowujac go do wypetniania obowiqzków rodzinnych i obywatelskich w oparciu o zasady solidarności, demokracji, tolerancji, sprawiedliwości i wolności." 14

Zadaniem edukacji jest zatem kształtowanie wartości uniwersalnych: prawdy, dobra, piękna. Wśród wartości współcześnie uznawanych za uniwersalne szczególne miejsce zajmuje też prawo do życia w wolności, podmiotowość i tożsamość człowieka, godność, odpowiedzialność, swobody obywatelskie, patriotyzm, życie wolne od zagrożeń wojna, demokracja, pluralizm polityczny i światopoglądowy, uczciwość, tolerancja, rodzina, edukacja, zdrowie i jego ochrona, możliwość samorealizacji, praca oraz godziwy poziom życia materialnego i duchowego. Wartości te stanowią źródło inspiracji oraz dyrektyw dla szkoły i edukacji. ${ }^{15}$

Historia ludzkości dowodzi, że ich deprecjacja zawsze kończyła się tragicznie. Dlatego, jak zauważa W. Prokopiuk, w obecnym procesie kształcenia pedagogów, szczególne miejsce winna zajmować aksjologia będąca alternatywą i odpowiedzią na błędne rozumienie pluralizmu i zagubienie teleologiczne. ${ }^{16}$ Ogromnym błędem, według wspomnianego autora, jest również rozdzielanie edukacji przyszłych nauczycieli na dwie części: naukowo-teoretycznej i kształtowanie kompetencji wychowawczych. Proponuje on, by w okresie kształcenia akademickiego, zgodnie z koncepcją humanistyczną, równolegle wykształcić ich najpełniejszą osobowość; w oparciu o wartości osobowe, duchowe oraz „gotowość do jej używania." 17

\footnotetext{
${ }^{14}$ Ustawa z dnia 7 września 1991 r. o Systemie Oświaty, [na:] http://www.menis.pl/ prawo oswiatowe.html z dn. 30.10.2008 r.

15 Por. Cz. Banach, Wartości w systemie edukacji, [na:] http://www. wsp.krakow.pl/ konspekt/konspekt7/banach7.html, z dn. 23.10.2008.

16 Por. W. Prokopiuk, Orientacja aksjologiczna..., dz. cyt., s. 16.

17 Tamże, s. 20.
} 


\section{OBRAZ WSPÓLCZESNEGO WYCHOWAWCY}

Wychowawca powinien zatem posiadać następujące cechy osobowości: aktywność intelektualną nastawioną na rozwiązywanie problemów, dobrze rozwinięte umiejętności intelektualne poparte solidnie skonstruowaną wiedzą. Wykształcenie tych cech często wymagać będzie zmiany roli nauczyciela. Opiekun nadal będzie centralnym ogniwem w procesie nauczania i wychowania, zmieni się natomiast jago rola jako przekaziciela samej wiedzy. Powinien stać się on diagnostykiem, konsultantem, twórcą środowiska wychowawczego. ${ }^{18}$

Dla zilustrowania omawianego problemu posłużę się niektórymi wynikami badań przeprowadzonych wśród grupy nauczycieli szkół średnich. W uzyskanych wynikach ujawniły się znaczne różnice w odpowiedziach pomiędzy nauczycielkami a nauczycielami. Kobiety za najważniejszą cechę uznały: posiadanie wiedzy i praktyki (33\%), bardzo wysoko akcentowały potrzebę rozwoju warsztatu pracy (23\%). Dalej umiejętność radzenia sobie w trudnych sytuacjach (18\%), na kolejnych miejscach zaznaczały umiejętność pracy z dziećmi (14\%), na końcu zaś znajomość rozporządzeń oświatowych (2\%). Natomiast nauczyciele na pierwszym miejscu, bardzo konkretnie zaznaczali sformułowanie „mistrz w swoim fachu” (35\%). Można to zinterpretować, jakoby mężczyźni chcieli być bardziej autorytetami w relacjach: mistrz - uczeń. $\mathrm{Na}$ drugim miejscu znalazła się odpowiedź posiadający wiedzę i praktykę (30\%), później lubiący pracę z dziećmi (18\%), następnie rozwój warsztatu (8\%). Jako najmniej istotne zakreślano odpowiedzi: umiejący radzić sobie w trudnych sytuacjach (4\%) oraz potrafiący rozwijać dzieci w różnych dziedzinach (4\%).

Zatem, według badanych, kompetentny wychowawca to osoba posiadająca wiedzę i praktykę zawodowa, charakteryzująca się nieustannym doskonaleniem posiadanych umiejętności i lubiąca pracę z uczniami. Ciekawym jest, że wszyscy badani nauczyciele najniżej ocenili znajo-

\footnotetext{
s. 165 .

18 Por. R. Pachociński, Oświata XXI wieku, Kierunki przeobrażeń, Warszawa 1999,
} 
mość rozporządzeń oświatowych (2 i 1\%). Powodem wydaje się być trwająca nieprzerwanie reforma systemu oświaty. Brak stałości i nieustanna dezaktualizacja przepisów nie sprzyja atmosferze przyswajania tychże dokumentów. Poza tym nie bez znaczenia pozostaje pytanie o czas, w którym mieli by to robić.

Interesujące wydają się być również odpowiedzi udzielone na pytanie dotyczące cech charakteryzujących kompetentnego wychowawcę.

Warto zaznaczyć, że obok różnic płci, w tym pytaniu bardzo mocno ujawniły się rozbieżności wynikające z uwarunkowań środowiskowych. Odpowiedzi udzielane przez nauczycieli z małych miejscowości odbiegały znacząco od odpowiedzi udzielanych przez osoby pracujące w dużych aglomeracjach. Za najważniejszą cechę zdecydowana większość wszystkich badanych uznała umiejętność nawiązywania kontaktów interpersonalnych (ok. 30\%) oraz umiejętność diagnozy sytuacji wychowawczej (ok. 27\%). Dalsze odpowiedzi nie były już tak zgodne. Nauczyciele mężczyźni jako kolejne istotne cechy zaznaczali: bogatą osobowość (15\%), doświadczenie zawodowe (7\%), umiejętność współpracy z rodzicami, duży zasób wiedzy merytorycznej i na końcu umiejętność współpracy z gronem pedagogicznym (1\%).

Ciekawą jest rozbieżność w odpowiedziach nauczycielek. Kobiety pracujące $w$ małych ośrodkach tuż po dwóch pierwszych odpowiedziach zaznaczały: umiejętność współpracy z rodzicami (19\%), bogata osobowość (15\%), doświadczenie zawodowe (7\%) i duży zasób wiedzy (6\%). Natomiast nauczycielki z dużych aglomeracji wyraźnie akcentowały duży zasób wiedzy (19\%), a dużo później umiejętność współpracy z opiekunami uczniów (6\%).

Intrygującym wydaje się fakt, że przytłaczająca większość badanych, jako ostatnią cechę wskazywała umiejętność współpracy z gronem nauczycielskim (1\%). Jest to o tyle zaskakujące, że w tym zawodzie współdziałanie jest bardzo pożądane. Moim zdaniem, wyniki obnażyły wielki nauczycielski indywidualizm. Jest on bardzo niepokojącym zjawiskiem, tym bardziej, że wychowanie dzieci i młodzieży wymaga zgodnej i szerokiej współpracy wielu grup i środowisk. Opierając się na udzielonych odpowiedziach można stwierdzić, że wyniki potwierdza- 
ją potrzebę prowadzenie szkoleń i warsztatów w zakresie umiejętności współpracy między nauczycielskiej. Zapewne okażą się one niezwykle przydatnym w tym, by nauczyciele nie traktowali się jak rywale, lecz wspólnie działali dla dobra powierzonej im młodzieży.

Omawiając zagadnienie kompetencji wychowawczych nauczycieli, zwrócono także uwagę na występujące $\mathrm{w}$ ich pracy trudności.

Praca w szkole zazwyczaj kojarzy się negatywnie. Powszechnie znane są trudności, z którymi boryka się dzisiejsza oświata. Owe kłopoty wpływają negatywnie nie tylko na samych pedagogów, ale także na atmosferę otaczającą całą edukację. Wyniki przeprowadzonego badania odsłoniły rozbieżność pomiędzy „medialną opinią” a stanem faktycznym. Przeglądając informacje na temat polskiej szkoły, możemy odnieść wrażenie, że głównymi problemami, z którym borykają się nauczyciele, są agresja wśród uczniów oraz trudności finansowo-ekonomiczne. Tymczasem z rozkładu odpowiedzi główną przeszkodą okazał się brak ambicji edukacyjnych uczniów (35\%) i ich zbyt duża liczba (19\%) w klasie. Co prawda, agresja (12\%) znalazła się na wysokim miejscu, jednakże o wiele więcej trudności powoduje zły kontakt z rodzicami (22\%). Słynne trudności ekonomiczno-finansowe były najniżej oceniane (1\%).

\section{WYCHOWAWCZY ETHOS}

Podstawą wszelkich nakładów na szkolnictwo jest założenie, że uczęszczanie przez dzieci do szkoły przyniesie kiedyś wymierna korzyść dla całego społeczeństwa. Dlatego też, praca nauczycieli-wychowawców, jak nazywa to Wolfgang Brezinka, zależy od sumienności zawodowej. Sumiennym zawodowo jest, według niego, ten, kto całkowicie i we wszystkim spełnia wymagania swego zawodu: posiada określoną wiedzę i umiejętności zawodowe, a także ethos zawodowy. ${ }^{19}$ W wielu szkołach i placówkach wychowawczych dominuje jednak ekonomizm wychowawczy oraz instrumentalne traktowanie uczniów. Brak

\footnotetext{
Por. W. Brezinka, Wychowywać dzisiaj, zarys problematyki, Kraków 2007,
} 232. 
poszanowania godności ucznia powoduje brak szacunku dla szkoły i nauczycieli.

Nie ulega wątpliwości, że polem działania pedagogów jest socjalizacja, polegająca na takim przygotowaniu młodych osób do życia w społeczeństwie. Dokonuje się to poprzez takie kształtowanie cech osobowości, by w swoim dorosłym życiu kierowali się w realizacji zamierzonych celów określonym i powszechnie uznawanym $\mathrm{w}$ danym kręgu kulturowym system wartości i norm. Przed pedagogami stają więc zadania: wspomagania, korygowania, animowania wrodzonych i nabywanych cech.

Dokonujące się zmiany w systemie oświatowym obok pojawiających się szans, stwarzają różne zagrożenia. Dlatego, jak zauważa Adam Solak, należy głównie przywrócić szkole jej wychowawcze funkcje, by obecny ,prymat wartości intelektualnych nie prowadzit do destrukcji wartości moralnych." ${ }^{20}$ Konsekwentnie taka argumentacja dowodzi, że - aby proces wychowawczy osiagnął zamierzony cel - musi uwzględniać wiele aspektów. Wśród nich wyszczególnić należy: wychowanie fizyczne, rozwój intelektualny, kształcenie oraz zdolności spostrzegania i kojarzenia, kierowania uczuciami i emocjami, rozwój moralny, woli, duchowy i społeczny. ${ }^{21}$

Praca pedagoga wymaga zatem od niego nie tylko wiedzy z zakresu pedagogiki, lecz także określonych zdolności opiekuńczo-wychowawczych wrodzonych, wykształconych w ciagu wielu lat zawodowych doświadczeń. Jest to istotne szczególnie teraz, gdy instytucje wychowawcze stają się drugim domem. Warto jednak pamiętać zawsze o tym, że żaden opiekun nie wytworzy takiej więzi emocjonalnej z dzieckiem, jak jego naturalni rodzice.

W naszych rozważaniach, aktualne pozostaje wciąż pytanie o cechy osobowościowe wychowawcy, a także o zakres jego wiedzy i umiejętności. Postawa pedagoga jest bowiem zasadniczym warunkiem zapewniającym skuteczne organizowanie procesu wychowania i kształcenia

20 Cyt za: A. Solak, Człowiek i jego..., dz. cyt. s. 143.
21 Tamże, s. 148 nn. 
osobowości ucznia. Określając te cechy, Wincenty Okoń stwierdza, że „doskonale wychowanie może być dzietem tylko doskonatego wychowawcy." 22 Dobra szkoła powinna być ponadto placówką oświatowa, nowoczesną, innowacyjną, zdolną do przekształcania się i zmieniania, czyli reagowania w sposób elastyczny na potrzeby uczestników procesu kształcenia i środowiska Zachodzące w niej relacje uczniowie - nauczyciel oparte powinny być na szacunku, a podporządkowanie zastępować winno partnerstwo. O potrzebie, a przy tym realnej możliwości tworzenia takiej nowej szkoły przekonuje w swej publikacji Kazimierz Denek. ${ }^{23}$ Natomiast Zygmunt Mysłakowski do najważniejszych cech wychowawcy zalicza: umiejętność kontaktu z młodzieżą, czynną sympatię, poszanowanie godności ludzkiej ucznia, szeroko rozumiany takt pedagogiczny, a więc zaufanie, sprawiedliwość, zgodność myśli z czynem oraz konsekwentność. ${ }^{24}$

Warto jeszcze wspomnieć o bardzo ciekawym ujęciu roli wychowawcy zaproponowanym przez Witolda Starnawskiego. Pisze on, że kolebką wychowania jest i zawsze będzie rodzina, choć ta prawda bywa często przemilczana. Szukając ideału wychowawcy, jego prawzoru, warto odnieść się do zależności tam panujących, bowiem relacje panujące między rodzicami a dziećmi powinny być wzorem układu wychowawca wychowanek. Wychowawca, aby dobrze wykonywać swoją misję, musi pamiętać o kilku fundamentalnych prawdach: po pierwsze, dziecko jest zależne od rodziców, zdane na ich pomoc, zaradność, dojrzałość. Dlatego też pedagog powinien być przede wszystkim tym, kto wie, wskaże drogę. Po drugie, podobnie jak rodzicom, została mu powierzona troska i odpowiedzialność za dziecko; ma je chronić przed złem oraz doprowadzić do pełnej doskonałości. Opieka rodziców polega także na przygotowaniu dziecka do samodzielności w życiu, z jednoczesnym umiejętnym wycofywaniem się z życia swoich pociech. Istotną cechą jest również optymizm wychowawcy; dobrzy rodzice zajmują się swoim dzieckiem

\footnotetext{
${ }^{22}$ Cyt za: W. Okoń, Osobowość nauczyciela, Warszawa 1962, s.7.

23 Por. K. Denek, Ku dobrej edukacji. Wszystko o wychowaniu. Nauczyciel, czy wychowawca, Torun-Leszno 2005, s. 66.

24 Por. W. Okoń, Wizerunki sławnych polskich pedagogów, Warszawa 2000, s. 310-312.
} 
bez względu na jego błędy i potknięcia. Nie oznacza to jednak, że je aprobują i nie uczą ponoszenia konsekwencji. Taką postawę winien przyjmować dobry wychowawca. Pedagog, jak i rodzice jest permanentnie włączony w proces wychowawczy. Powinien pamiętać, że jest on jego uczestnikiem, a nie obserwatorem. Wychowankowie potrafią uczyć swoich opiekunów, w jaki sposób mają się nimi zajmować, o ile ci drudzy potrafią to odczytywać. To z kolei wymaga stałej obecności i miłości wychowawczej. ${ }^{25}$

Wychodząc z założenia, że osobowość wychowawcy wyznacza działanie i myślenie pedagogiczne, można śmiało stwierdzić, że spełnia on obok rodziców, centralną rolę w wychowaniu młodych ludzi. Wymienione wyżej wskazania wydają się być najprostszą wskazówką dla wszystkich, którzy swą pracę zawodową pragną realizować z pasją, uczynić z niej źródło życiowej satysfakcji, a jednocześnie ustrzec się przed grożącą rutyną i szybkim wypaleniem zawodowym.

\section{PODSUMOWANIE}

Żyjemy w czasach charakteryzujących się nieustannymi przeobrażeniami również w sferze edukacji i nauki. Społeczeństwo oczekuje, że to głównie pedagodzy staną się odpowiedzialni za wychowanie przyszłych pokoleń. Wymaga to wypracowania nowego modelu wychowawcy, który unikając rutyny i nadmiernego trzymania się utartych schematów oraz powierzchowności, jest gotowy i otwarty na zmiany, dąży do kreatywności, a także modyfikacji wykonywaniu czynności pedagogicznych.

Stając u progu nowego stulecia nie trudno dostrzec przemiany dokonujące się na gruncie szeroko ujmowanego wychowania. Przejście od stylu autorytarnego i demokratycznego w kierunku liberalizacji rodzi wiele dylematów. Zwykle dotyczą one braku proporcjonalności między wymaganiami a swoboda, spontanicznością a racjonalnością. Pedagodzy stawiają szereg pytań o zakres i jakoś ingerencji rodziców,

25 Por. W. Starnawski, Prawda podstawa wspólnoty, wychowawcza rola prawdy wedtug Karola Wojtyly, Warszawa 2005, s. 177-179. 
nauczycieli, wychowawców w rozwój indywidualny dzieci i młodzieży, a także dotyczących norm i granic wychowania. Pedagogika zajmuje się zawsze kwestią wartości człowieka. Takiego bowiem będziemy mieli człowieka, jakiego sobie teraz wychowamy. Kreujemy „image” osób, które będą żyły dalej. W świecie wartości istnieje zawsze jakaś wizja, jakaś antropologia. Do celu wcale nie musimy przekonywać, ale pokazać że jesteśmy w stanie go osiąnnąć. Talent pedagogiczny istnieje, okazuje się ze nie jest on jednorodny, w jakimś stopniu leży w naturze człowieka, tak jak predyspozycja do rodzicielstwa.

\section{BIBLIOGRAFIA}

Bartkowiak Z., Kowaluk M., Samujło M., Nauczyciel kompetentny, teraźniejszość i przyszłość, Lublin 2007.

Brzezinka W., Wychowanie i pedagogika, $W$ dobie przemian kulturowych, Kraków 2005.

Brzezinka W., Wychowywać dzisiaj, zarys problematyki, Kraków 2007.

Czerepaniak-Walczak M., Aspekty i źródła profesjonalnej refleksji nauczyciela, Torun 1997.

Denek K., Ku dobrej edukacji. Wszystko o wychowaniu. Nauczyciel, czy wychowawca, Toruń-Leszno 2005.

Dudzikowa H., Czerepaniak-Walczak M., Wychowanie: Pojęcia Procesy-Konteksty, Gdańsk 2007.

Gospodarek T., Jasiński Z., Edukacja w procesie przemian cywilizacyjnych i kulturowych, Opole 1993.

Horny G., Hall E., Hall C., Nauczyciel wychowawca, Gdańsk 2005

Kobyłecka E., Nauczyciel wobec współczesnych zadań edukacyjnych, Kraków 2005.

Łobocki M., W trosce o wychowanie w szkole, Kraków 2007.

Okoń W., Nowy Stownik Pedagogiczny, Warszawa 2004.

Okoń W., Osobowość nauczyciela, Warszawa 1962.

Okoń W., Wizerunki stawnych polskich pedagogów, Warszawa 2000.

Pachociński R., Oświata XXI wieku, Kierunki przeobrażeń, Warszawa 1999. 
Pilch T. (red.), Encyklopedia Pedagogiczna XXI wieku, t. 3, Warszawa 2005.

Pomykało W., Encyklopedia pedagogiczna, Warszawa 1993.

Solak A., Człowiek i jego wychowywanie. Zagadnienia wybrane, Tarnów 2004.

Speck O, Trudności wychowawcze, być nauczycielem w czasie zmian społeczno-kulturowych, Gdańsk 2007.

Starnawski W., Prawda podstawa wspólnoty, wychowawcza rola prawdy wedlug Karola Wojtyly, Warszawa 2005.

Wilk J., Współczesny wychowawca w stylu księdza Bosko, Materiaty z sympozjum z okazji 100-lecia pracy salezjanów w Polsce, Katolicki Uniwersytet Lubelski 16-17.04.1998, Lublin 1998.

Wołoszyn S.(red), Źródta do dziejów wychowania i myśli pedagogicznej, Myśl pedagogiczna w XX wieku, t.3, Kielce 1998.

Wołoszyn S., Janusz Korczak, Warszawa 1982.

Banach Cz., Wartości w systemie edukacji, [na:] http://www. wsp.krakow.pl/konspekt/konspekt7/banach7.html, z dn. 23.10.2008.

Malinowski J. A., Nauczyciel jako dobry wychowawca, Wychowanie szkolne a reforma sytemu edukacji, [na:] http://www.szkolna.pl/akapit/ nauczyciel.html, z dn.19.10.2008.

Salamucha A., Definicje wychowania w literaturze pedagogicznej, [na:] http://www.kul.lublin.pl/art_3322.html, z dn.23.10.2008.

Ustawa z dnia 7 września 1991 r. o Systemie Oświaty, [na:] http:// www.menis.pl/prawo_oswiatowe.html z dn. 30.10.2008 r. 